\title{
Colon cleansing before colonoscopy: Does oral sodium phosphate solution still make sense?
}

\author{
Douglas K Rex MD FACP FACG ${ }^{1}$, Stephen J Vanner MSc MD FRCPC ${ }^{2}$
}

DK Rex, SJ Vanner. Colon cleansing before colonoscopy: Does oral sodium phosphate solution still make sense? Can J Gastroenterol 2009;23(3):210-214.

Oral sodium phosphate $(\mathrm{NaP})$ solution has been withdrawn from the market in the United States but remains available for over-the-counter purchase for bowel preparation for colonoscopy in Canada. The present review summarizes recent data regarding the renal toxicity of oral $\mathrm{NaP}$ as well as its efficacy and tolerability relative to other preparations. Given the availability of effective alternatives to $\mathrm{NaP}$ solution, its use for colonoscopy preparation in Canada should be limited. Candidate patients for oral $\mathrm{NaP}$ solution should be assessed for eligibility and preparation instructions should adhere to the current recommendations for maximizing the safety of oral $\mathrm{NaP}$.

Key Words: Bowel preparation; Colonoscopy; Sodium phosphate

Oolon cleansing in preparation for colonoscopy continues to be a significant challenge for physicians and patients. The demand for colonoscopy continues to increase in North America and worldwide, largely in response to national colon screening programs. This demand has placed significant stress on existing colonoscopy resources. Effective colon cleansing becomes increasingly important in this environment because poor cleansing impacts the duration of the procedure and the interval recommended between procedures. The ability of the patient to tolerate the preparation is also important, because it can affect the quality of the preparation and has been identified as the most important factor underlying patient compliance in colonoscopy surveillance programs (1). Oral sodium phosphate $(\mathrm{NaP})$ solution emerged in the 1990s as a popular colon cleansing agent because of favourable efficacy and patient tolerability $(2-4)$. However, safety issues have emerged which have led to questions concerning the risk/benefit of this agent $(5,6)$. The present article provides an overview of the qualities of an optimum colon cleansing preparation, the relative advantages and disadvantages of oral $\mathrm{NaP}$ solution, and the emerging trends and alternatives in colon cleansing. The present review provides a context for which the question of 'whether the use of oral $\mathrm{NaP}$ solution still makes sense', for bowel preparation in Canada, can be examined.

\section{QUALITY OF THE OPTIMUM COLON CLEANSING REGIMEN}

There are three fundamental components to the optimum colon cleansing preparation: cleansing efficacy, patient tolerability and safety. Cleansing efficacy affects the polyp detection

\section{La vidange du colon avant la coloscopie : La solution de phosphate de sodium par voie orale $a-t$-elle encore du sens?}

La solution de phosphate de sodium $(\mathrm{NaP})$ par voie orale est retirée du marché aux États-Unis mais offerte en vente libre au Canada pour les préparations intestinales de coloscopie. La présente analyse résume les données récentes au sujet de la toxicité rénale de la $\mathrm{NaP}$ par voie orale ainsi que de son efficacité et de sa tolérabilité par rapport à d'autres préparations. Puisqu'il existe des préparations efficaces pour remplacer la solution de $\mathrm{NaP}$, il faudrait en limiter l'usage pour les préparations de coloscopie au Canada. Il faudrait évaluer les patients candidats à une solution de $\mathrm{NaP}$ par voie orale afin de déterminer leur admissibilité et de s'assurer que les directives de préparation respectent les recommandations actuelles afin de porter l'innocuité du $\mathrm{NaP}$ par voie orale au maximum.

rate $(7,8)$ and duration of the procedure $(9)$, and can influence the duration between colonoscopies in screening programs. Cleansing in the right colon is particularly important because this region presents the greatest challenge $(10,11)$. Furthermore, there is increased recognition that flat polyps have significant premalignant potential and are preferentially found in the right colon $(12,13)$. Patient tolerability of the preparation is also very important because it can lead to morbidity and, rarely, mortality (eg, vomiting resulting in Boerhaave's syndrome); indirectly affects the quality of the cleansing (eg, patient cannot ingest the full preparation); and is recognized to be an important determinant of compliance in colon screening programs (1). The issue of safety is magnified by the increasing number of healthy patients undergoing an elective procedure to prevent disease and by an aging population being subjected to colonoscopy. Ultimately, these factors must also be balanced against the implications of missing a clinically significant lesion (eg, flat polyp with high-grade dysplasia or carcinoma) due to poor cleansing or noncompliance due to concerns about the cleansing regimen which may result in a serious adverse outcome (eg, interval colon cancer in a screening program).

\begin{abstract}
Assessment of oral $\mathrm{NaP}$ solution as an optimum cleansing agent

Since the original study comparing two $45 \mathrm{~mL}$ oral doses of $\mathrm{NaP}$ with $4 \mathrm{~L}$ of polyethylene glycol (PEG) solution almost 20 years ago (2), numerous studies have reported findings that support the original study. Two meta-analyses $(14,15)$ of these studies (Table 1) have been conducted, which demonstrated that $\mathrm{NaP}$
\end{abstract}

University, Kingston, Ontario.

Correspondence and reprints: Dr Douglas Rex, Indiana University Medical Center, 4100-550 North University Boulevard, Indianapolis 46202,

USA. Telephone 317-278-8741, fax 317-274-5449, e-mail drex@iupui.edu

Received for publication July 24, 2008. Accepted July 28, 2008 
provides superior colon cleansing, particularly when given in a night/morning split dosage (see split-dose regimens below), and is much better tolerated than 4 L PEG solutions. However, split-doses of PEG were typically not used in these studies.

It has been well recognized that oral $\mathrm{NaP}$ solution has potential safety issues because it is a small-volume osmotic agent with the ability to draw fluid from the intravascular space and cause transient hyperphosphatemia (4). However, extensive clinical trials failed to demonstrate any clinically significant sequelae resulting from these actions (4). A review in the early 2000s (4) documented that more than 2500 patients had been studied in clinical trials and there were no reports of serious adverse events. There have been a small number of case reports documenting serious adverse events; however, these appeared to be the result of inappropriate dosing and/or patient selection (eg, patients with contraindications such as renal failure or bowel obstruction). Data from the United States Food and Drug Administration (FDA) and Health Canada in early 2000 suggested the serious adverse event rate, including mortality, was similar for NaP and PEG (4). However, in 2003, a case report (16) suggested an association between chronic renal failure and nephrocalcinosis with the use of oral $\mathrm{NaP}$ for colon cleansing. This was followed the next year by a case series of 23 patients (5) detected from a large database of renal biopsies. The risk factors are not entirely clear, but female sex, cocomitant use of medications such as diuretics, angiotensinconverting enzyme inhibitors/angiotensin receptor blockers, underlying subclinical renal disease and the hydration status of the patient have been suggested as possible associations $(5,6,17)$. Recent retrospective and prospective studies specifically examining the impact of $\mathrm{NaP}$ on renal function have not clearly identified a systematic decline in renal function (Table 2). However, of the five retrospective studies (18-22), the largest (22) reported an OR of 2.35 (doubling of serum creatinine; number needed to harm $=298$ ). Three prospective studies $(18,23,24)$, two of which are reported in abstract form only $(23,24)$, have not revealed an association between the use of oral $\mathrm{NaP}$ and the subsequent development of renal failure. Despite these findings, small numbers of case reports suggesting an association between the use of oral $\mathrm{NaP}$ and renal failure
TABLE 1

Meta-analyses of studies comparing efficacy and tolerability of oral sodium phosphate (NaP) and polyethylene glycol (PEG)

\begin{tabular}{lcc}
\hline & Hsu and Imperiale (14) & Tan and Tjandra (15) \\
\hline Trials, $n$ & 8 & 16 \\
Efficacy & $\mathrm{NaP} \geq \mathrm{PEG}(4 \mathrm{~L})$ & $\mathrm{NaP}>\mathrm{PEG}(4 \mathrm{~L})$ \\
Tolerability & $\mathrm{NaP}>\mathrm{PEG}$ & $\mathrm{NaP}>\mathrm{PEG}$ \\
\hline
\end{tabular}

continue to emerge $(25,26)$. Most experts believe that there is an association but that the risk is low.

The United States FDA issued a safety alert in December 2008 , stating that oral $\mathrm{NaP}$ for colon cleansing before colonoscopy should only be available by prescription. As a result, the CB Fleet Company (Lynchburg, USA) immediately issued a voluntary recall of their over-the-counter products for colon cleansing in the United States. The FDA's issuance followed a review after "it received more than 20 reports of a rare, but serious from of kidney failure among patients taking the drugs, known as oral phosphate products". More details can be found on the FDA Web site (www.fda.gov/medwatch/safety/2008/ safety08.htm\#OSP). NaP tablets remain available in the United States, but the FDA recommended that their use be restricted to appropriate candidates who are 55 years of age and younger.

To date, oral $\mathrm{NaP}$ solution remains available as an over-the-counter product for colonoscopy in Canada.

\section{CURRENT TRENDS TOWARD OPTIMIZING THE USE OF ORAL NaP AND ALTERNATIVE CLEANSING REGIMENS}

In the past decade, lower dose solutions, split dosing, and a mixture of sodium picosulfate, magnesium oxide and citric acid (Pico-Salax [Ferring Inc, Canada] - presently not available in United States) - have been introduced as newer strategies.

There is growing interest, particularly in the United States, in the use of lower-dose preparations of PEG, oral $\mathrm{NaP}$ and $\mathrm{NaP}$ tablets (Table 3). Low-dose PEG solution (2 L) combined with bisacodyl tablets (Halflytely [Braintree Laboratories Inc, USA] - not available in Canada) have been shown to improve

TABLE 2

Published studies examining the effects of sodium phosphate (NaP) and polyethylene glycol (PEG) on renal function

\begin{tabular}{|c|c|c|c|}
\hline Author (reference) & Design & Primary outcome & Major finding \\
\hline Abaskarhoun et al (18) & $\begin{array}{l}\text { Retrospective } \\
\text { NaP, } n=600 \\
\text { PEG, } n=150\end{array}$ & Serum creatinine above normal range & No association with use of $\mathrm{NaP}$ \\
\hline Brunelli et al (19) & Nested case-control; n=2237 & $\begin{array}{l}\text { Serum creatinine }>25 \% \text { from baseline or } \\
\text { increase of }>44 \mu \mathrm{mol} / \mathrm{L}\end{array}$ & No association with use of $\mathrm{NaP}$ \\
\hline Hurst et al (22) & $\begin{array}{l}\text { Retrospective observational cohort } \\
\text { NaP, } n=6432 \\
\text { PEG, } n=3367\end{array}$ & $\begin{array}{l}\geq 50 \% \text { increase in baseline serum creatinine } \\
\quad \text { NaP, } n=83 \\
\text { PEG, } n=31\end{array}$ & $\begin{array}{l}\text { 1. Multivariate analysis: NaP increased risk } \\
\text { 2. NaP OR=2.35 } \\
\text { 3. Doubling of serum creatinine: } \\
\quad \text { Number needed to harm }=298\end{array}$ \\
\hline Singal et al (21) & $\begin{array}{l}\text { Retrospective } \\
\text { NaP, } n=157 \\
\text { PEG, n=154 }\end{array}$ & Change in serum creatinine from baseline & $\begin{array}{l}\text { NaP resulted in minor increase in serum creatinine } \\
(8.8 \mu \mathrm{mol} / \mathrm{L}) \text { not believed by authors to } \\
\text { be clinically significant (only reached significance } \\
\text { when compared with } \mathrm{PEG} \text {, which decreased } \\
\text { serum creatinine) }\end{array}$ \\
\hline Russman et al (20) & $\begin{array}{l}\text { Retrospective cohort } \\
\text { PEG, n=269 } \\
\text { NaP, } n=2083\end{array}$ & $\begin{array}{c}\text { Glomerular filtration rate }<60 \mathrm{~mL} / \mathrm{min} \text { and } \\
\text { decrease from baseline of }>10 \mathrm{~mL} / \mathrm{min}\end{array}$ & No association with use of $\mathrm{NaP}$ \\
\hline
\end{tabular}


TABLE 3

Summary of 'low dose' polyethylene glycol (PEG) studies

\begin{tabular}{|c|c|c|c|c|}
\hline Author (reference) & Design & Efficacy & Tolerability & Comments \\
\hline DiPalma et al (27) & $\begin{array}{l}\text { Bisacodyl and } 2 \text { L PEG }(n=93) \text { versus } \\
4 \text { L PEG }(n=93)\end{array}$ & No difference & Greater & $\begin{array}{l}\text { More inadequate preparations } \\
\text { with } 2 \text { L dose + bisacodyl }\end{array}$ \\
\hline Adams et al (28) & $\begin{array}{l}\text { Bisacodyl and } 2 \text { L PEG }(n=191) \text { versus } \\
\quad 4 \text { L PEG }(n=191)\end{array}$ & No difference & Greater & - \\
\hline Johanson et al (29) & $\begin{array}{l}\text { Bisacodyl and } 2 \text { L PEG }(n=202) \\
\text { versus NaP tablets }(n=200)\end{array}$ & Less effective & Less tolerable & $\mathrm{NaP}$ tablets \\
\hline Balaban et al (30) & $\begin{array}{l}\text { Bisocodyl and } 2 \text { L PEG }(n=41) \\
\text { versus } \mathrm{NaP}(n=80)\end{array}$ & Less effective & No difference & Published as abstract only \\
\hline
\end{tabular}

NaP Oral sodium phosphate

\section{TABLE 4}

Effect of 'split dosing' of polyethylene glycol (PEG) and sodium phosphate (NaP) on efficacy

\begin{tabular}{|c|c|c|c|}
\hline Author (reference) & Solution & Study design & Conclusion \\
\hline Rostom et al (10) & $\mathrm{NaP}$ & $\begin{array}{l}\text { Two } 45 \mathrm{~mL} \text { doses of NaP taken } 6 \mathrm{~h}, 12 \mathrm{~h} \text { or } 24 \mathrm{~h} \text { apart. } \\
6 \mathrm{~h} \text { doses were taken evening before the procedure; } 12 \mathrm{~h} \text { and } 24 \mathrm{~h} \\
\text { regimens had second dose the morning of procedure }\end{array}$ & $\begin{array}{l}12 \mathrm{~h} \text { or } 24 \mathrm{~h} \text { preparation most effective } \\
\text { (ie, regimen with dose morning of procedure) }\end{array}$ \\
\hline Aoun et al (34) & PEG & $\begin{array}{l}4 \text { L PEG night before procedure versus } 2 \text { L PEG night before and } \\
2 \text { L PEG morning of procedure }\end{array}$ & $\begin{array}{l}\text { Split-dose PEG was more effective, no } \\
\text { difference in tolerability }\end{array}$ \\
\hline Parra-Blanco et al (35) & PEG and $\mathrm{NaP}$ & 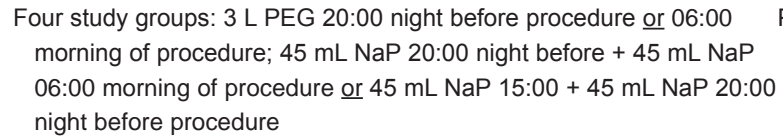 & $\begin{array}{l}\text { PEG or NaP with second dose given on the } \\
\text { same day of the procedure provided the } \\
0 \text { greatest efficacy }\end{array}$ \\
\hline
\end{tabular}

TABLE 5

Recommendations to minimize risk of adverse events with the use of oral sodium phosphate

\begin{tabular}{|c|c|c|c|}
\hline Patient selection & Absolute contraindications & \multicolumn{2}{|l|}{ Other considerations* } \\
\hline $\begin{array}{l}\text { Essential to screen all patients } \\
\text { before colonoscopy }\end{array}$ & $\begin{array}{l}\text { Renal failure } \\
\text { Congestive heart failure, ascites } \\
\text { Significant ischemic heart disease } \\
\text { Ileus or bowel obstruction } \\
\text { Pregnancy } \\
\text { Younger than } 18 \text { years of age } \\
\text { Inability to follow instructions or ensure } \\
\text { adequate hydration }\end{array}$ & \multicolumn{2}{|c|}{$\begin{array}{l}\text { Medications: diuretics, angiotensin-converting enzymes/angiotensin receptor } \\
\text { blockers }\end{array}$} \\
\hline \multirow[t]{2}{*}{ Maintain hydration } & Before colonoscopy & During colonoscopy & After colonoscopy \\
\hline & $\begin{array}{l}\text { Encourage } 2 \mathrm{~L}-3 \mathrm{~L} \text { fluids over evening } \\
\text { and up to } 2 \mathrm{~h} \text { before colonoscopy; } \\
\text { oral rehydration solution if tolerated } \\
\text { (eg, Gatorade [Pepsi-QTG, Canada]) }\end{array}$ & $\begin{array}{l}\text { Infuse saline during procedure if } \\
\text { intravenous in place }\end{array}$ & $\begin{array}{l}\text { Encourage fluids when patient leaves } \\
\text { endoscopy suite }\end{array}$ \\
\hline Proper dosing & Dosing interval & Dose & \\
\hline $\begin{array}{l}\text { Minimizes phosphate load and } \\
\text { intravascular volume shift }\end{array}$ & $\begin{array}{l}10 \mathrm{~h} \text { to } 12 \mathrm{~h} \text { apart; best cleansing if } \\
\text { second dose given the morning of the } \\
\text { procedure }\end{array}$ & \multicolumn{2}{|c|}{$\begin{array}{l}45 \mathrm{~mL} / 45 \mathrm{~mL} \text { dose in Canada (do not increase dose or repeat if preparation } \\
\text { poor) }\end{array}$} \\
\hline
\end{tabular}

*See text for additional comments

patient tolerance over the standard $4 \mathrm{~L}$ dose, and studies $(27,28)$ did not detect differences in efficacy. However, the studies were not designed as equivalence trials and one study showed a significant increase in inadequate preparations in the low-dose group (27). Therefore, it remains possible that these lower volume preparations are not as efficacious. There are limited data comparing this lower volume of PEG with oral $\mathrm{NaP}$ $(29,30)$ but the available data suggests less efficacy than with oral NaP (Table 3). Similarly, lower doses of oral NaP (45/30 mL - not available in Canada) are now marketed which should reduce the osmotic effect and phosphate load. Studies (31) have not detected a difference in efficacy between the low dose and standard dose but there were numerically more preparations with poorer cleansing in the lower-dose group, especially in men.
Thus, there is some concern that the reduced oral $\mathrm{NaP}$ dose may compromise efficacy in some patients. Recent studies $(32,33)$ examining a decreased number of $\mathrm{NaP}$ tablets did not detect differences in efficacy compared with standard tablet doses.

Split dosing has emerged as an important factor in cleansing efficacy and may also impact patient tolerability in large volume preparations (Table 4). This factor has become increasingly important as colonoscopy units expand their examination times from the morning to the full day. There is growing supportive data for all bowel preparations that the quality of the preparation declines considerably when the interval from the last dose exceeds $12 \mathrm{~h}$, and possibly between $6 \mathrm{~h}$ to $12 \mathrm{~h}(10)$. Studies (Table 4 ) have shown that split dosing with $\mathrm{NaP}$ and PEG enhances efficacy $(10,34,35)$. 
Pico-Salax was recently introduced in Canada and has been used in the United Kingdom since 1981. In Canada, it has become increasingly popular among patients and physicians. A recent review (36) suggests this agent is better tolerated than standard regimens of $\mathrm{NaP}$ and PEG and has a very good safety profile (based on small studies with safety data and the paucity of serious adverse event reporting). However, the efficacy of this agent remains to be established because it is unclear whether the efficacy is similar to $\mathrm{NaP}$ and PEG (36).

\section{CONCLUSIONS}

The role of oral $\mathrm{NaP}$ solution as a colonic cleansing agent is evolving and its future is unclear. In response to recent the FDA directives, oral $\mathrm{NaP}$ solution is no longer available as a colon cleansing agent in the United States but it remains available in Canada as an over-the-counter product. Given the safety concerns with this agent, the recent regulatory developments in the United States, and the recent availability of alternative products in Canada, United Kingdom, Europe and Australia that better meet the criteria of an 'optimum bowel preparation' (eg, Pico-Salax with or without adjunct[s]) it is difficult to advise the continued use of oral $\mathrm{NaP}$ solution unless

\section{REFERENCES}

1. Harewood GC, Wiersema MJ, Melton LJ III. A prospective, controlled assessment of factors influencing acceptance of screening colonoscopy. Am J Gastroenterol 2002;97:3186-94.

2. Vanner SJ, MacDonald PH, Paterson WG, Prentice RS, Da Costa LR, Beck IT. A randomized prospective trial comparing oral sodium phosphate with standard polyethylene glycol-based lavage solution (Golytely) in the preparation of patients for colonoscopy. Am J Gastroenterol 1990;85:422-7.

3. Barkun A, Chiba N, Enns R, et al. Commonly used preparations for colonoscopy: Efficacy, tolerability, and safety - a Canadian Association of Gastroenterology position paper. Can J Gastroenterol 2006;20:699-710.

4. Hookey LC, Depew WT, Vanner S. The safety profile of oral sodium phosphate for colonic cleansing before colonoscopy in adults. Gastrointest Endosc 2002;56:895-902.

5. Markowitz GS, Stokes MB, Radhakrishnan J, D'Agati VD. Acute phosphate nephropathy following oral sodium phosphate bowel purgative: An under-recognized cause of chronic renal failure. J Am Soc Nephrol 2005;16:3389-96.

6. Heher EC, Thier SO, Rennke H, Humphreys BD. Adverse renal and metabolic effects associated with oral sodium phosphate bowel preparation. Clin J Am Soc Nephrol 2008;5:1494-503.

7. Rex DK. Maximizing detection of adenomas and cancers during colonoscopy. Am J Gastroenterol 2006;101:2866-77.

8. Chiu HM, Lin JT, Wang HP, Lee YC, Wu MS. The impact of colon preparation timing on colonoscopic detection of colorectal neoplasms - a prospective endoscopist-blinded randomized trial. Am J Gastroenterol 2006;101:2719-25.

9. Kossi J, Kontula I, Laato M. Sodium phosphate is superior to polyethylene glycol in bowel cleansing and shortens the time it takes to visualize colon mucosa. Scand J Gastroenterol 2003;38:1187-90.

10. Rostom A, Jolicoeur E, Dube C, et al. A randomized prospective trial comparing different regimens of oral sodium phosphate and polyethylene glycol-based lavage solution in the preparation of patients for colonoscopy. Gastrointest Endosc 2006;64:544-52.

11. Gupta T, Mandot A, Desai D, Abraham P, Joshi A, Shah S. Comparison of two schedules (previous evening versus same morning) of bowel preparation for colonoscopy. Endoscopy 2007;39:706-9.

12. Park DH, Kim HS, Kim WH, et al. Clinicopathologic characteristics and malignant potential of colorectal flat neoplasia compared with that of polypoid neoplasia. Dis Colon Rectum 2008;51:43-9.

13. Brooker JC, Saunders BP, Shah SG, et al. Total colonic dye-spray increases the detection of diminutive adenomas during routine colonoscopy: A randomized controlled trial. Gastrointest Endosc 2002;56:333-8. physicians and/or patients have a specific need that cannot be met by alternative products (eg, patient unable to tolerate other agents). If so, physicians and patients must be aware of its potential safety concerns and take appropriate measures to ensure that these risks are minimized. Contraindications to its use need to be strictly adhered to (Table 5) and the importance of adequate hydration stressed; oral $\mathrm{NaP}$ solution should be avoided in the extremes of age. $\mathrm{NaP}$ tablets are not available in Canada, and in the Unites States, the FDA has recommended that the use of prescription $\mathrm{NaP}$ tablets be restricted to low-risk patients (ie, younger than 55 years of age). Prescription use of tablets should follow practices outlined for $\mathrm{NaP}$ solution (Table 5).

CONFLICTS OF INTEREST: SV has served on the speaker bureau and advisory board for the CB Fleet Company and Ferring USA. He has received unrestricted educational grants from Pharma Science Canada, CB Fleet Company and Ferring Canada. He holds a patent on oral rehydration solutions and colon cleansing. DR has served on the advisory board and has received research support from the CB Fleet Company and Salix Pharmaceuticals.

14. Hsu CW, Imperiale TF. Meta-analysis and cost comparison of polyethylene glycol lavage versus sodium phosphate for colonoscopy preparation. Gastrointest Endosc 1998;48:276-82.

15. Tan JJ, Tjandra JJ. Which is the optimal bowel preparation for colonoscopy: A meta-analysis. Colorectal Dis 2006;8:247-58.

16. Desmeules S, Bergeron MJ, Isenring P. Acute phosphate nephropathy and renal failure. N Engl J Med 2003;349:1006-7.

17. Markowitz GS, Radhakrishnan J, D'Agati VD. Towards the incidence of acute phosphate nephropathy. J Am Soc Nephrol 2007;18:3020-2.

18. Abaskharoun R, Depew W, Vanner S. Changes in renal function following administration of oral sodium phosphate or polyethylene glycol for colon cleansing before colonoscopy. Can J Gastroenterol 2007;21:227-31.

19. Brunelli SM, Lewis JD, Gupta M, Latif SM, Weiner MG, Feldman HI. Risk of kidney injury following oral phosphosoda bowel preparations. J Am Soc Nephrol 2007;18:3199-205.

20. Russmann S, Lamerato L, Marfatia A, et al. Risk of impaired renal function after colonoscopy: A cohort study in patients receiving either oral sodium phosphate or polyethylene glycol. Am J Gastroenterol 2007;102:2655-63.

21. Singal AK, Rosman AS, Post JB, Bauman WA, Spungen AM, Korsten MA. The renal safety of bowel preparations for colonoscopy: A comparative study of oral sodium phosphate solution and polyethylene glycol. Aliment Pharmacol Ther 2008;27:41-7.

22. Hurst FP, Bohen EM, Osgard EM, et al. Association of oral sodium phosphate purgative use with acute kidney injury. J Am Soc Nephrol 2007;18:3192-8.

23. Korsten MA. Bowel cleansing prior to colonoscopy: Evidence for renal toxicity in a randomized, prospective trial using oral sodium phosphate (OSP) and polyethylene glycol (PEG). Gastrointest Endosc 2007;65:103 (Abst).

24. Balaban DH, Harlan WR, Beavers KL, Thompson WO, Moe SM, Pambianco DJ. Multicenter longitudinal evaluation of the renal effects of sodium phosphate bowel preparation. Am J Gastroenterol 2005;100:S353 (Abst).

25. Beyea A, Block C, Schned A. Acute phosphate nephropathy following oral sodium phosphate solution to cleanse the bowel for colonoscopy. Am J Kidney Dis 2007;50:151-4.

26. Carl DE, Sica DA. Acute phosphate nephropathy following colonoscopy preparation. Am J Med Sci 2007;334:151-4.

27. DiPalma JA, Wolff BG, Meagher A, Cleveland M. Comparison of reduced volume versus four liters sulfate-free electrolyte lavage solutions for colonoscopy colon cleansing. Am J Gastroenterol 2003;98:2187-91. 
28. Adams WJ, Meagher AP, Lubowski DZ, King DW. Bisacodyl reduces the volume of polyethylene glycol solution required for bowel preparation. Dis Colon Rectum 1994;37:229-33.

29. Johanson JF, Popp JW Jr, Cohen LB, et al. A randomized, multicenter study comparing the safety and efficacy of sodium phosphate tablets with $2 \mathrm{~L}$ polyethylene glycol solution plus bisacodyl tablets for colon cleansing. Am J Gastroenterol 2007;102:2238-46.

30. Balaban DH, Malik P, Thompson WO. Comparison of two dosing regimens of liquid sodium phosphate against a low dose PEG regimen. Am J Gastroenterol 2005;100:S354.

31. Rex DK. Dosing considerations in the use of sodium phosphate bowel preparations for colonoscopy. Ann Pharmacother 2007; $41: 1466-75$.

32. Rex DK, Chasen R, Pochapin MB. Safety and efficacy of two reduced dosing regimens of sodium phosphate tablets for preparation prior to colonoscopy. Aliment Pharmacol Ther 2002;16:937-44.
33. Rex DK, Schwartz H, Goldstein M, et al. Safety and colon-cleansing efficacy of a new residue-free formulation of sodium phosphate tablets. Am J Gastroenterol 2006;101:2594-604.

34. Aoun E, Abdul-Baki H, Azar C, et al. A randomized single-blind trial of split-dose PEG-electrolyte solution without dietary restriction compared with whole dose PEG-electrolyte solution with dietary restriction for colonoscopy preparation. Gastrointest Endosc 2005;62:213-8.

35. Parra-Blanco A, Nicolas-Perez D, Gimeno-Garcia A, et al. The timing of bowel preparation before colonoscopy determines the quality of cleansing, and is a significant factor contributing to the detection of flat lesions: A randomized study. World J Gastroenterol 2006;12:6161-6.

36. Hookey LC, Vanner S. A review of current issues underlying colon cleansing before colonoscopy. Can J Gastroenterol 2007;21:105-11. 


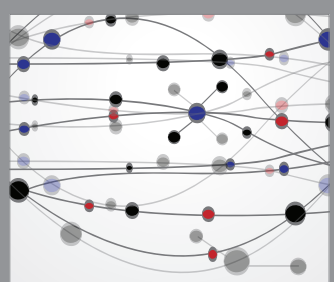

The Scientific World Journal
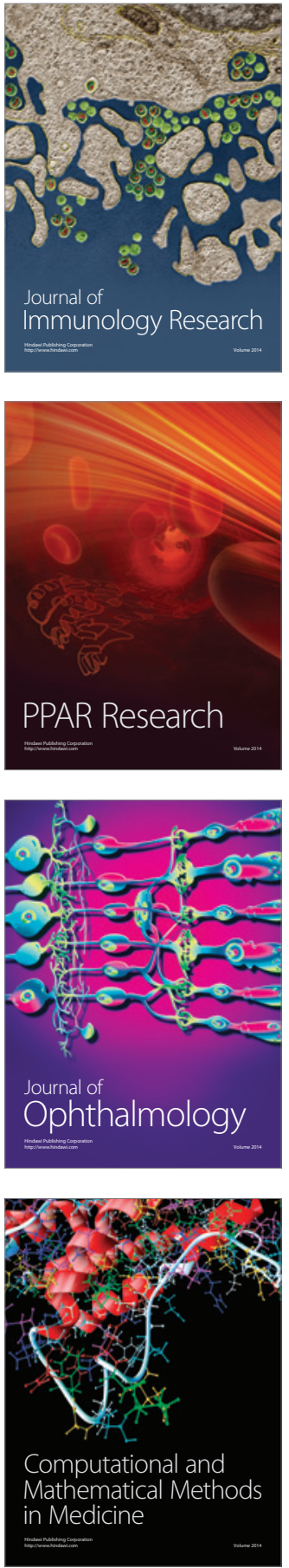

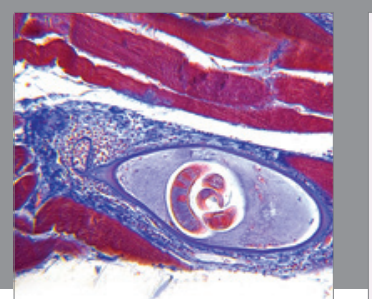

Gastroenterology Research and Practice

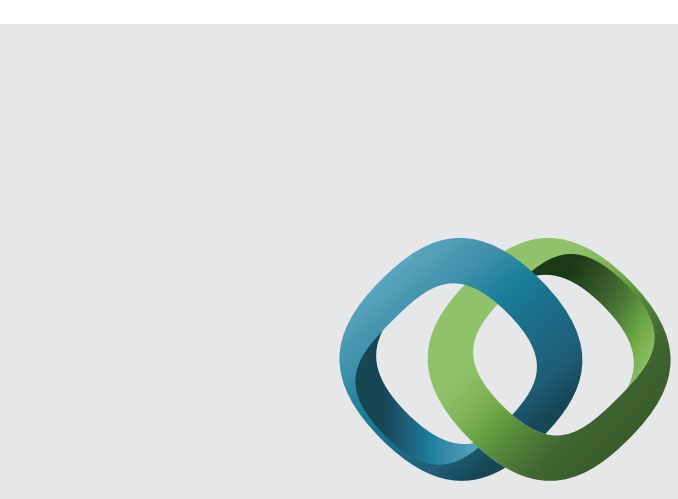

\section{Hindawi}

Submit your manuscripts at

http://www.hindawi.com
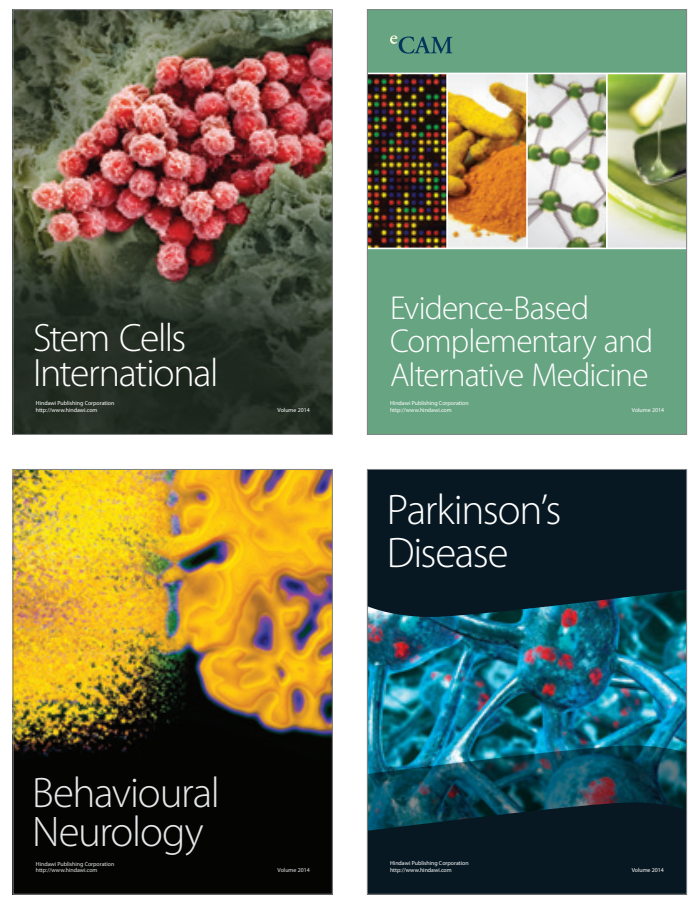
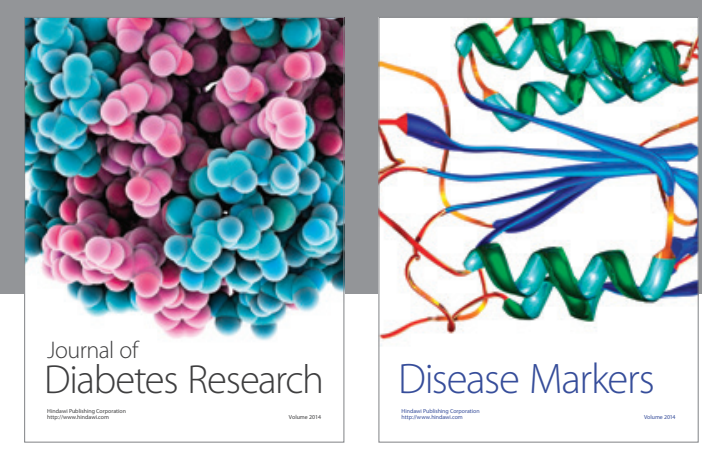

Disease Markers
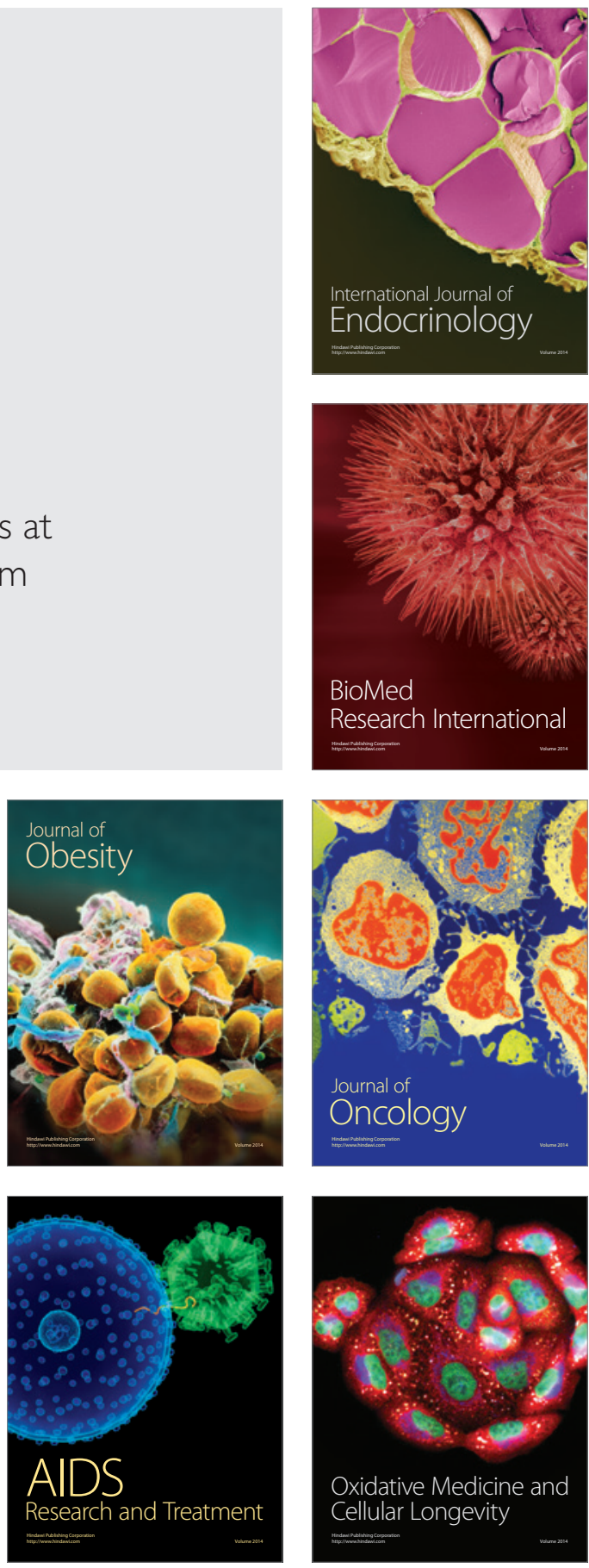